\title{
Beyond Content. On the Form in Sound Art
}

\author{
Natalia KOWALSKA-ELKADER, PhD \\ Department of Journalism and Social Communication \\ Faculty of Philology \\ University of Lodz, Poland \\ E-mail: natalia.kowalska@uni.lodz.pl \\ ORCID: 0000-0002-9726-8227
}

\begin{abstract}
Form in sound art is the crucial aspect for both analysis and perception. The theoretical basis includes, among others, the theory of 'Pure Form' devised by Stanistaw Ignacy Witkiewicz and Susan Sontag's theory of interpretation. Later in the text, issues of aesthetics and anti-aesthetic are mentioned. The research questions dealt with in this text were: What is the position of form in sound art and how is it related to content? What kinds of means of expression can be applied? The employed methods include literary analysis and criticism as well as some elements of structural analysis. The examples analyzed in this article were broadcasts by Gregory Whitehead, Eugeniusz Rudnik, Tomasz Plata, and Antye Greie. The perception of the art can be disturbed by certain means of expression such as formal chaos or noise which is also considered in the text.
\end{abstract}

Keywords: Experiment; Form; Content; Radio art; Sound. 
"In place of a hermeneutics, we need an erotics of art" (Susan Sontag)

\section{Introduction}

Allen S. Weiss argues that there is no one radio, "rather a multitude of radios. Radio broadcasting is heterogeneous, with all levels of instrumentation, practice, forms, and utopias" (Weiss, 2001, 2). He searches for a way to show diversity in a short presentation of concepts about non-mainstream radio: Rudolf Arnheim, Wielimir Chlebnikow, Bertolt Brecht, or the cut-up narrative collages of William Burroughs. "Each 'radio' defines its ideal world, creates it between utopia and dystopia" (Weiss, 2001, 2). Based on this utopian-dystopian vision of radio and its specific forms, genre determinants and theoretical assumptions are created, which are to reflect the living and constantly changing sound matter, including the artistic and experimental.

In this text, I present issues related to the theoretical assumptions of art and its form, and I will use sound works of an experimental nature as examples. In addition to the positions of sound researchers, a key concept will be Stanisław Ignacy Witkiewicz's theory of pure form, the assumptions of which seem to be extremely relevant concerning the formal aspects of artistic radio works. I will also refer to the considerations of Susan Sontag. Further, I will also discuss anti-aesthetics and the anti-artistic means of expression. The research questions I ask myself are related to the way of creating experimental works, their form, and their relation to the content. The methods I will use in this text are literary analysis and criticism, as well as elements of structural analysis of the programs I have cited.

Joe Milutis, in an article devoted to radio ontology and the avant-garde, writes that "Avant-garde radio art tries to create a sound bridge via impenetrable dead signs ... to real radio, even though it is fully aware of the impossibility of regaining truth through representation practices" (Milutis, 2001, 58). He also describes avant-garde or experimental radio art as "using schizophonia, thereby filling the inner space of radio reception with many voices and sounds, disrupting traditional visions of what the tape, the music or the ear interpreting the apparatus can withstand" (Milutis, 2001, 59). The multitude of these voices to some extent reflects reality and at the same time distorts it; radio experiments depart from the real representation of events, and rather - often through their form - only refer to them. Art subjects the environment to processes aimed at changing the way it is perceived shifts the burden of the question "what?" to try to answer the question "how?".

Following Gregory Whitehead, Milutis sees the radio space as "a distracted nervous system, in constant crisis, visible in radio works such as Pressures of the Unspeakable or To Have Done with the fudgement of God, it is already an operational prerequisite for bridging the gap between word and thing, theatre and life, enabling either a revolutionary leap into new perceptual and productive relationships or a 
descent into madness" (Militius, 2001, 61). Both works cited by the researcher present the author's perspective, thus reminding us of how strongly the art of sound is related to the creator and his point of view.

I treat representations of sound art as works of art in general and it is from this perspective that I will be examining them. Stanisław Ignacy Witkiewicz (aka Witkacy, Polish writer, painter, philosopher, playwright, and photographer), whose assumptions of pure form I will return to later, defines them as follows: "in general, we can define a work of art as a construction of any simple and complex elements, created by an individual as an expression of the unity of his personality and operating directly through constructivism itself" (Witkiewicz [1921] 1932, 20). The strongly accentuated figure of the author once again reminds us of the key importance of his perspective in the work. I pay attention to this fact because artistic radio representations, especially quasi-documentaries, often fall victim to content analysis, which aims to check their credibility and socio-historiographical usefulness.

Both Sontag's and Witkacy's statements are frequently considered as the referring points for art criticism and analysis but since they mostly referred to visu$\mathrm{al}$ arts it is a new perspective to relate their findings with sound art (KowalskaElkader, 2021). Sound art as a media art field is still unrecognized and not formally described. I find it important to place this kind of audial expression among the research perspective. The examples I chose are very different and represent diverse forms and topics. It not only shows the variety of sound art but also gives a fuller picture of how they can relate with art criticism, pure form, and anti-aesthetic. The Pure Form is an old concept but still reflects well the formal approach to the art including sound art-the form much younger than itself.

\section{Sound art.}

\section{Structure, form, examples}

Sound art may display some connections with artistic radio documentaries, but the effects of a sound artist's work are not subject to journalistic restrictions, such as the requirement of objectivity, even if they deal with real events. The author filters the story, characters, or events through his own experiences, and transforms the sounds. The importance of the author's predisposition and attitude towards the work being created, as well as the reality in which it is created, was also noticed by Witkacy ([1921] 1932, 30): "insignificant, but necessary". Radio artist Gregory Whitehead took a somewhat unusual position on the Pan-American discussion of contactless torture in the broadcast On the Shore Dimly Seen (ABC Radio National, Australia 2015). The basis for its creation was the protocol disclosed by the Time magazine from the interrogation of the arrested 063, Mohammed al Qahtani. Whitehead was responsible for the editing and composition of the documentary, its 
directing, narrative, and vocal parts. Singer Gelsey Bell performs musical improvisations and actress Anne Undeland acts as the narrator. As part of this program, the creator develops a socially important topic, interprets it, and thus becomes part of the discourse on US policy. This is not a journalistic production, but the use of the protocol in its original form-the hours included in the transcript of the interrogation are also read, i.e., meta-discursive elements-places on the Shore ... within the spectrum of documentary and artistic programs, undoubtedly in experimental form.

An extremely important aspect of works of art is their form, although as tukasz Guzek $(2010,7)$ writes, "formalism, the very principle of seeking new forms and methods of creation, related to the pattern of the modernist avant-garde, has been negated by postmodernism and rejected as 'art for art's sake' in favour of content (discourse)". This means that also in sound art, the audience seems to focus on what the author is telling them about, and not on how he does it and how the message is structured. The structure of the work by Jan Mukařovský $(1970,23)$ determines the form and its final shape; he treats it as "a whole that defines the nature of its elements (...) in short: hierarchy, mutual inferiority, and superiority of components. (...) the unstable balance of constantly moving forces".

The relational nature of the individual components of the structure is important: relationships between the elements and their dynamics have a direct impact on the final effect. The mutually dynamic elements include, among others: voice materials, music, sound effects, editing and the use of technology, silence, phonic gestures, and sound metaphors.

However, the structure of experimental works is living tissue, as it evolves with each new representation. As G. Whitehead postulated (n.d., 89): "I firmly believe that radio creators must find a way to disrupt the boundaries of 'sound art', for most of them sound tired and familiar anyway". For Whitehead, radio is transmitted through sound, but the sound is not its core, because what is most important is the relational nature of the elements involved in the whole system: "bodies and antibodies, host and parasite, pure noise and irresistible facts: all this in a bizarre parade with a goal unknown, fragile, uncertain" (Whitehead, n.d., 89). This uncertainty is related to the transience of the radio message, the anonymity of the listener, and the randomness of listening while wandering around the signals in the air, but it has been replaced-at least partially—by listening on-demand, podcasts, and the intentionality of reception.

The structure as a set of elements in a work, the relationship between them, and their relation to the whole become a construct, the study of which should also include the influences to which a given work of art is subjected, introducing a field of comprehensive interpretation, where signs and meanings are evenly distributed. René Wellek and Austin Warren (1974, 329-330) argued that "instead of juxtapos- 
ing 'form' and 'content', we use the concepts of 'matter' and 'form' as what aesthetically organizes 'matter'." The holistic understanding of the experiment means that it can be treated and understood as an aesthetic experience, which emphasizes the overriding function of this type of implementation - the aesthetic function. Structure and form are also elements that give meaning, and their specific arrangement not only frames the work but also speaks of its individual elements. As Stanisław Ignacy Witkiewicz wrote,

"Starting from the howl of a suffering man, we can move almost continuously to a symphony. As intermediate elements, we can take, for example, various types of singing, from an indistinct humming to a specific melody, and finally, we end up with a perfectly constructed piece of music. All these species of phenomena will have qualitative elements, sounds, put into certain forms: from complete arrhythmia to a definite rhythm, because the form can become complicated in such a way that the last elements of the series may, at first glance, or rather the ear, seem completely formless" (Witkiewicz [1921] 1932, 9).

The form of the work is also its content, and the alignment of these components means that the genre pattern does not contain any elements that distinguish them either. The construction of audial experimental works is the final form, and it should be analysed, interpreted, or simply perceived.

A good example is the history of Russian feminism presented in the album Dissidentova (AGF Production, 2018) by Antye Greie (AGF). The album is based on the stories of fifteen cult Russian female figures; the spoken word was based on fragments of their statements, letters, and poetry. Regarding the AGF Project (2020, 1), she says:

"My intention is to create a transformative work that inspires and destroys fossilized constructs such as gender bias or claims that a certain culture must sound a certain way. Everyone was surprised how many women I edited during my work. I do not think it is a question of quantity now, but I try to make my works strong in their message, politicised and give a voice to previously oppressed voices".

The formal aspects of the works: a musical arrangement co-created by Russian artists, a combination of contemporary music and historical statements, as well as structural elements such as repetitions, broken words, seemingly chaotic editing, co-create-to use the previously mentioned concept-the matter of Dissidentova. The form of individual compositions is of no small importance, as it shows how the author perceives her heroines and how she would like them to be perceived within her work. 


\section{Form and content.}

\section{Susan Sontag's and audio art}

Artistic discourse has accepted the opposition between form and content, and as Susan Sontag $(2018,12)$ writes that it was art's defense that contributed to the birth of the peculiar notion that what we define as 'form' is separate from that what we refer to as 'content' understood in good faith as essential, as opposed to the form which is considered auxiliary. The importance attached to the content is extremely high, and regardless of whether we consider the work as a representation (art as a representation of reality) or as a statement (art as an artist's statement), the content remains the most important. It can change, become less figurative, less literal, and realistic. However, it is still assumed that a work of art is its content or, as is usually said today, that a work of art says something by definition (Sontag, 2018, 12-13). So, what can Eva's palindromic piece Can I Stab the Bats in the Cave? say, from the album Disorder Speech (Minerva Editions, 1985) by Gregory Whitehead? What, in my opinion, is crucial, inverting the Sontag analogy, is that it is, and it shows what it is: it is aleatoric, inverting the meaning of the words used, self-referential. In turn, in the less than three-minute story about the voice in If A Voice Like, Then What?, also included in Disorder Speech, the author, through the transformation of speech, subjecting it to numerous procedures of analogue editing, realizes a piece in which she presents her view of the word, voice, and its possible use in audio art through the structure and form.

Although according to Sontag, artistic achievements, their research, and interpretations distract us, it would seem, farther and farther from the conviction that the work is primarily its content, this idea still prevails almost completely (Sontag, $2018,13)$. However, it is not the purpose of radio art to implement a slogan, close to both reporters and writers, to show not tell. It is not the most important thing to show what you want to say, but to strive for newer and more unique forms that determine what the author intended to accomplish.

The outstanding Polish radio experimenter Eugeniusz Rudnik (Polish sound director and composer, pioneer of electronic and electroacoustic music) perceived the narrative spatially, translating the collage technique into the language of sounds, the "essence of which is in simultaneity" (Rudnik cited in Solakiewicz, 2013, 21). The structure of his works reflected the belief that a sound is a three-dimensional event and that this is how radio pieces should be composed:

"You think linearly - with successive events. In the audio narrative, it may be that some important events and clusters follow one another, but at the same time in the second and third sound planes, they can resonate simultaneously. On decay, in the middle of one important event, something from the background, from the third and the fourth may be banging. It is like a threedimensional space" (Rudnik cited in Solakiewicz, 2013, 21). 
The method of structuring the sound material gave the broadcast a spatial character, apart from the course from the beginning to the end of the broadcast, its depth and acoustic planes can be analysed. Working with sound planes is one of the most characteristic elements of Rudnik's work. He operated with the spatiality of sound both in pieces created individually, such as in Lekcja (Polish Radio 1959) and Lekcja II (Polish Radio 1965), Peregrynacjach Pana Podchorążego albo Nadwiślańskich Żarnach (Radio Lublin 1999) or in co-authored productions, like Sekunda Wielkamała suita dokumentalna dla dorostych (with A. Kaczkowska, Radio Lublin 1995).

Equally important is that the effect of over-emphasizing the role of content is a never-ending endeavour of interpretation. And vice versa - the habit of communing with the work to interpret it maintains the illusion that there really is something like the content of the work of art (Sontag, 2018, 14). Interpretation as a change in the text hidden under an apparent attempt to find its meaning is strongly opposed by the essayist. She also notices that work can be subdued by reducing it to its content and interpreting this very content (Sontag, 2018, 17). Reducing a radio work only to its content and focusing all attention on it will mean that the acts of formal experimentation present in radio art from the very beginning of its existence will cease to be relevant.

Using the example of American prose and drama, Sontag formulates the thesis that those areas of art that did not have a strong avant-garde movement are susceptible to interpretation. When ideas about what can be done with form are banal, secondary, and conservative, then content, even if it is not simply presenting information or facts, is still more visible, accessible, and exposed (Sontag, 2018, 21). The researcher sees the failure of authors to strive to work on the evolution of form to be vulnerable to attacks of interpretation. Striving for the importance of the form, its uniqueness, and continuous development contribute to its purity and importance. In art, including experimental radio works, what is not of the highest value is mimicry or giving the audience the ability to identify with a certain aspect of the work. What is important in art is the distance to reality because in the end "style" is art. Art, on the other hand, is nothing more than various types of stylized, dehumanized representation. Overcoming or transcending the world in art also means facing the world and teaching the will to exist in the world (Sontag, 2018, 48).

Art formal nature and programmatic avant-gardism mainly involve experimenting with the form at the expense of content (Sontag, 2018, 21). The division into form and content in art is apparent, but also extremely obvious because everything should have a formal aspect and develop it.

\section{The Pure Form by Stanisław Ignacy Witkiewicz}

Stanisław Ignacy Witkiewicz, mentioned earlier, wrote about the purity of form. Regarding sounds, he claimed: "What given combinations of sounds express, we 
will call their life content, as opposed to the form which we will define as only a certain order of sequence in time" (Witkiewicz [1921] 1932, 9-10). The development of a sound structure is the implementation of a fixed-or previously unpredictable, as in the case of some experiments-form. In the sound system of Ziggurat from the album Disorder Speech, Whitehead explores the possibilities of analogue editing as well as the rhythmic possibilities of sounds and voice and creates a threedimensional space that detaches words from their original meaning. The work of Gregory Whitehead is characterized by sharp cuts of sounds, compositions composed of seemingly incompatible elements, and surprising arrangements. The structure of this piece, as well as of the others from the album Disorder Speech, follows Witkiewicz's definition of form, which says that "form is that which gives a certain unity to complex objects and phenomena" (Witkiewicz [1921] 1932, 14).

Witkacy combines the concept of form with beauty, which he understands in two ways:

"The concept of Beauty is then differentiated into the notion of Life Beauty, related to the life usefulness of an object or phenomenon, and the concept of Formal Beauty, which merely describes the order, form, i.e., constructiveness of the object or phenomenon. It will be beauty in a strict artistic sense" (Witkiewicz [1921] 1932, 13-14).

Therefore, if formal beauty comes from what is artistic, it is in the form that the essence of works of art should be sought. If the aesthetic function is considered to be the superior function of artistic and artistic-experimental works, one can use the notion introduced by Witkiewicz:

„I call the form that works by itself, causing aesthetic satisfaction, Pure Form. So, it is not a form devoid of content, because no living creature can create such a form, only one in which life components are a secondary element" (Witkiewicz [1921] 1932, 15).

Contrary to Sontag, Witkiewicz does not deprive art of its content, nor does he deny the existence of the two-component essence of a work of art, but it is in form-like the American researcher-that he sees the quintessence of artistic activities. The author of the study on Pure Form interprets the dynamics of content and form based on the example of music interestingly:

"What will be the role of the life elements now, polluting even the most abstract Pure Form. In music, the elements of life are feelings. Music can be either a means of expressing them or it can be merely a pretext for a certain dynamic tension and qualitative colouring of the parts that make up a piece of music. In the latter case, we are dealing with Pure Form in music. (...) With the help of this (Pure Form-author's note) we can eliminate the concept of an object and its deformation from aesthetics, a concept that implies the 
concept of an imitation of this object, and further, the concept of reality in general, which obscures the simple view of art" (Witkiewicz [1921] 1932, 15).

For Witkiewicz, Pure Form is both a goal in his artistic activities and a way to achieve it. Each attempt to search for a new form of expression introduces the creator to the path of formal activities, and this search is a response to the outdated separation of form and content in art.

Witkiewicz understood the act of creation as a set of actions whose individual elements do not have full creative autonomy: "The creative process is homogeneous; only when describing it, do we need to list the components of its dependent moments." (Witkiewicz [1921] 1932, 16). The form determines the perception of art and placing it in the centre of the analysis is very common. Formal analysis is also one of the first steps in Feldman's art critic method (Feldman, 1970, Kowalska-Elkader, 2021, 156-167). Roy Ascott $(1990,229)$ shares this opinion and argues that art "meaning/content is no longer something which is created by artists, then distributed through the network and received by the recipient. Meaning is rather the result of an interaction between the observer/participant and the system, the content of which is in a state of flux, (...) until it is reconstituted at the interface as image, text or sound".

\section{Anti-aestheticism in sound art}

One of such aspects, the nature of which seems to be extremely dependable, and whose character changes dramatically beyond the work, is anti-aesthetic elements. In isolation from the convention adopted in the work, anti-aesthetic agents cease to function in the way that was possible in the work, they lose their artistic value, as exemplified by noise. It is worth emphasizing that a piece based on anti-aesthetics is ambiguous and often incomprehensible:

"It is enough to accept the fact that the work of anti-art is ambiguous, incomprehensible, and does not succumb to discursive reconstruction. It is available only to those who overcome the initial shock and move to the positions of these new searches, bearing intellectual and emotional risks together with the creator, related to e.g., experience, reception" (Gołaszewska, 1984, 184).

In order to become fully acquainted with it, the viewer must overcome the aesthetic shock and accept the need to search for new means of perception for which he was not prepared through contact with the old, non-avant-garde forms of art.

In the definition of aesthetic shock, Maria Gołaszewska draws attention to the moment when the threshold of sensitivity to a stimulus is exceeded and the process of art reception is interrupted (Gołaszewska, 1984, 131). The viewer, according to the researcher, may then react aggressively or become discouraged, giving up con- 
tacts with contemporary art; though some artists are focused on using these reactions to arouse strong emotions. "Avant-garde art very often confronts the viewer with the necessity of a radical change in the aesthetic attitude, adopting the violently imposed manner of perceiving a work of art, sometimes even changing the understanding of art altogether. And this is what often causes an aesthetic shock", concludes Gołaszewska $(1984,135)$.

The Shell Shock broadcast puts the listener to the test. It was produced by Komuna Warszawa, with Tomasz Plata being the originator and author of the text, and the music being prepared by Aleksandra Grünholz. The drama presents an alternative story about the Polish avant-garde, its protagonists being Władysław Strzemiński and Stanisław Ignacy Witkiewicz as WW1 veterans who, in new abstract forms and radical manifestos, look for a remedy against the front-line trauma. Shell Shock breaks with the dramatic assumptions of radio theatre, abandoning the plot in favour of a series of slogans, which in some parts take the form of a libretto for electronic musical compositions. It uses polyphonic without content as a nonverbal but not asemantic use of speech. Plata's realization, belonging to sound art, reflects in form what appears in the textual layer: "Form is the value. The content does not create a form (...). Pure form, pure form, pure form.” Although Tomasz Plata did not base the work on anti-aesthetic measures in its entirety, by giving up the classic plot structure, dispersing the narrative, and employing the avant-garde manner of expression, he could have caused the listener a state of shock. You may get a similar impression when acoustic anti-aesthetics are used, as with the vocalizations and noises in On the Shore Dimly Seen, which I have already mentioned. Some of the sound materials used are irritating, too high-pitched, or unfriendly, and repulsive, which undoubtedly affects the reception of the broadcast and may discourage you from listening to it.

Gołaszewska notes that "anti-aesthetics, in opposition to aesthetics, sets itself separate goals and tasks. For example, it does not try to explain a work of art, does not analyse or interpret it - it considers this to be sufficiently discredited by crude exegesis, which bores not only high school students but also the public and critics" (Gołaszewska, 1984, 184). These tasks and goals are directed towards art, not towards the recipient who should submit to it. This changes the structure of the aesthetic situation, as well as the values so far assigned to artistic objects:

"A work in the sense of an artistically shaped object disappears, the difference between the creator and the recipient also disappears; and what affects the new situation the most is the complete change in the function of aesthetic value - value, placed outside the work, becomes merely an elusive utopia. Aesthetic experience equips things with values." (Gołaszewska, 1984, 185).

The aesthetic situation also changes due to the values that are present in the work, as well as how they are expressed. The anti-aesthetic quest uses unconven- 
tional solutions that are usually not associated with artistic activities: utility items, emergencies, and their visual or sound representations, waste, and others:

„anti-art, with all awareness and almost accepting passion, introduces negative values into its scope, such as horror, rape, violence, degeneration. Antiart is made of everything - not only tin cans, the air of an empty exhibition hall but also the real agony of man, road accidents, watching evil with a cold eye" (Gołaszewska, 1984, 185).

Eugeniusz Rudnik used in his broadcasts sounds played on cans or with the use of discarded fabrics, stones, pipes, and also reused sounds from which other broadcasts were cleaned before archiving, he called them vile matter, unworthy sounds. These are all kinds of unsuccessful or unused and forgotten fragments of broadcasts that got a second chance thanks to him. He collected and catalogued "nonsense", "bangs", "clanks", "discharges", "effusions", coughs and other imperfections (Karow, n.d.). He said about such materials:

„My garbage is not sloppy garbage (...). It must be a dry dumpster. The trash in the sense of unnecessary things that were once needed and ceased to be important for some reason. They interested me by their rejection, that they were dismissed, degraded - considered unsuccessful (...). This trash must touch me. It must have an emotional value. And if it doesn't, and I suspect it did, then I provide it through the context. Through the neighbourhood" (Rudnik cited in Solakiewicz, 2013, 23).

The composer gave new meaning to individual sounds, small fragments, or entire sequences by putting them together appropriately. He also built new qualities out of them, which made their primal ugliness an advantage, while at the same time rendering them inaudible.

Stanisław Ignacy Witkiewicz also referred, although in a slightly different way, to anti-aesthetic:

„It is also characteristic of works of art that elements which are so unpleasant: unpleasant combinations of colours, musical dissonances, bizarre, unpleasant and disturbing, and even repulsive combinations of words and actions, may, in totality, be necessary elements of its unity in the whole of a given work, that is, its artistic beauty. It is the composition of the whole of the elements that are unpleasant in themselves and their advantage in a given work is what I call artistic perversion" (Witkiewicz [1921] 1932, 20).

Elements that he described as unpleasant, bizarre, or disturbing derive precisely from the anti-aesthetic resource of artistic means. Witkiewicz reads the necessity to use this artistic perversion as a sign of the times, claiming that it was once possible to create a work of art without the use of such means, "today, against the background of the hectic pace of life, social mechanization, exhaustion of all 
means of action and artistic indifference, it has become necessary to use perverse means"(Witkiewicz [1921] 1932, 20), and Witkacy perceives realism as "a symptom of a temporary collapse"(Witkiewicz [1921] 1932, 20).

Experimental art departs from imitation, but here too the words of Witkacy apply, that "it is impossible to objectively and strictly separate realism from formalism. For each individual, this boundary may lie in a different place in the series, although we will be able to define some rather distant elements as realistic, others as formalistic" (Witkiewicz [1921] 1932, 23). In radio experiments of a quasi-documentary nature, the characters or situations the author refers to are often real. The Stone Epitaph (1984) by Rudnik, a broadcast commemorating Father Jerzy Popiełuszko, is a composition consisting exclusively of non-verbal sound materials. The work is devoid of straightforward brutality, the sounds are neither violent nor sharp; punctuated by the increasing sounds of the tapes, they evoke the impression of spaciousness and the conscious use of acoustic planes. Rudnik said about the broadcast: "When this crime was committed, it became fashionable to sing 'God, something, Poland" in churches. I don't feel these passionate atmospheres. I went to the field, attached contact microphones to the stones-because the stones were also tied to Popiełuszko's legs. I hit them with other stones, wood, iron” (Lech, n.d.). The references to the protagonist are thus expressed in the form of a certain sonic synecdoche, in which the entire memory and its sonic representation are reduced to one type of sound material. These sounds can therefore be understood both as realistic because natural noises and para-musical materials have been registered, but also as formalistic, due to the way the content of the work is reflected in them and the way they are used.

The reception of anti-aesthetic and experimental works requires the listener to have a high level of perceptive competencies, as well as a tendency to overcome difficulties appearing in the perceptual process related to aesthetic shock. According to Witkiewicz, people "are incapable of overcoming reality in art, they cannot experience artistic impressions. They are those who, not understanding Pure Form, as well as realists, are looking for a deformed reality in art. They are realists 'â rebours' ('in reverse'-author's note)" (Witkiewicz [1921] 1932, 30). It is interesting because certain deformations of reality have permanently stuck to the art of sound. Artists change natural sounds, adapt them to their needs and ideas, and subject them to numerous editing procedures. Natural sound materials and the human voice are changed, and despite these processes, the search for reality in art is still part of the interpretation process. Witkacy argued that it was "naturalism that left behind the illusion of objective criteria in the form of reality with which its reproduction in the art can be compared" (Witkiewicz [1921] 1932, 24). However, an attempt to recreate reality is in fact contradictory to the basic artistic assumptions of the experiment, according to which the goal is aesthetic satisfaction, the realization of the form (or Pure Form). Witkiewicz, on the other hand, says about the interpretation that 
„there is a certain impassable limit of the work's identity with itself, which cannot be exceeded by interpretation. If a given work of art, or e.g., a piece of music, finds values in general through a realistic or sentimental interpretation, without becoming something good in these dimensions, it proves that the formal element prevails in it and vice versa. Via misinterpretation, you can turn a perfect formal thing into a realistic cock-and-bull story without value and turn a good realistic drama into formal nonsense. (...) So if someone desperately wants to see in painting a deformed or non-deformed external world as such, and in theatre, a faithfully reflected or grotesque and caricatured reality, he will never be aesthetically satisfied" (Witkiewicz [1921] 1932, 29).

Thus, like Susan Sontag, Witkacy postulates a departure from the standard interpretation of the text, in which the recipient adjusts the message to himself and the surrounding reality. It would be utopian, however, to demand that art be perceived in isolation from one's own experience, taste, or without comparison to previously known works. Witkiewicz was also aware of this: "it is absolutely impossible to objectively evaluate works of art and to criticize them because a significant relationship to them is based on subjectivism" (Witkiewicz [1921] 1932, 24). The manner of reception is much more real where the form of the work is the central element of perception. This is how Witkacy formulated this thought: "However, one should expect viewers and listeners to have a certain attitude towards adopting the formal, not life values of works of art" (Witkiewicz [1921] 1932, 26).

\section{Conclusion}

The manner of reception is extremely important in the entire aesthetic situation. Experimental art is demanding for the recipient, and anti-aesthetic may cause reactions that are not caused by art based on aesthetic assumptions, and "the recipient, who cannot meet the artist's requirements and remains outside the sphere of new art, usually turns to old art, which, it seems to him, is susceptible to the way of experiencing it which is in line with his habits and type of sensitivity to beauty" (Gołaszewska, 1984, 127). In turn, the departure from realism towards artistic and anti-aesthetic activities, liberated from the accepted aesthetics, is characteristic of all experimental activities. These are actions aimed at form, therefore "we must adopt the initial assumption that the essence of art is form" (Witkiewicz [1921] 1932, 13).

Diverse examples and the variety of sound art forms and topics show that this artistically rich field can still be the place for future in-depth research. What is extremely important is the fact that all kinds of categories or genre classification always will be secondary to all artistic activities. 


\section{References}

1. Ascott, R. (1990). Beyond Time-Based Art-ESP, PDP \& PU, "Zeit", special issue of the magazine Sterz, Graz.

2. Gołaszewska, M. (1984). Estetyka i antyestetyka, wyd. Wiedza Powszechna, Warsaw.

3. Greie, A. (AGF). email sent to the author on 21.01.2020.

4. Guzek, Ł. (2010). Funkcja dokumentacji w sztuce współczesnej. Sztuka i dokumentacja, 3.

5. Feldman, E. B., (1970), Becoming Human Through art: Aesthetic Experience in the School, Englewood Cliffs, New Jersey: Prentice Hall.

6. Karow (n.d.) Zbieracz dźwięków niechcianych. Retrieved January 12, 2020 from http:// www.teatr-pismo.pl/przestrzenie-teatru/1729/zbieracz_dzwiekow_niechcianych/

7. Kowalska, N. (2020). Historie eksperymentalne. Szkice o gatunkach radia artystycznego, Łódź: University of Lodz Publishing.

8. Kowalska, N. (2020). Poza treścią. O formie w sztuce dźwiękowej. In J. Bachura-Wojtasik, N. Kowalska-Elkader (eds.), Stowo, dźwięk, cisza. Radio i sztuka audialna. Łódź: University of Lodz Publishing.

9. Kowalska-Elkader N. (2021). Przełożenie metod badania sztuk wizualnych na sztukę audialną - metoda krytyczna Edmunda Feldmana w badaniu artystycznego dzieła radiowego. In A. Barańska-Szmitko (ed.), Metody badania komunikacji i mediów. Perspektywa teoretyczna i analityczna, Łódź: University of Lodz Publishing (in print).

10. Losiak, R. (2012). Autentyczność dźwięków. Kulturowy kontekst schizofonii. Kultura Współczesna, 1(72), 94-101.

11. Milutis, J. (2001). Radiophonic Ontologies and the Avantgrade. In Weiss, A. (ed.), Experimental Sound \& Radio. Cambridge: MIT Press.

12. Mukařovský, J. (1970). Estetyczna funkcja, norma i wartość jako fakty społeczne. In Wśród znaków i struktur. Warsaw: Państwowy Instytut Wydawniczy.

13. Solakiewicz, Z. (2013). Na zasadzie gestu. In Studio Eksperyment. Warsaw: Fundacja Bęc Zmiana.

14. Sontag, S. (2018). Przeciw interpretacji. In Przeciw interpretacji i inne eseje. Kraków: Karakter.

15. Lech, F. (n.d.). Krajobraz po Rudniku. Retrieved February 1, 2020 from https://noweperyferie.pl/index.php/2016/10/krajobraz-po-rudniku/.

16. Weiss, A. S. (2001). Radio Icons, Shirt Circuits, Deep Schisms. In Weiss, A. (ed.), Experimental Sound \& Radio. Cambridge: MIT Press.

17. Whitehead, G. (2001). Radio Play is No Place. A Conversation between Gregory Whitehead and Jerome Noetingder. In Weiss, A. (ed.), Experimental Sound \& Radio. Cambridge: MIT Press.

18. Whitehead, G. (n.d.). Wings of Eros on Birds of Prey, typescript of the article in the possession of the author.

19. Witkiewicz, S. I. (1932). O czystej formie. Warsaw: Library Z. 